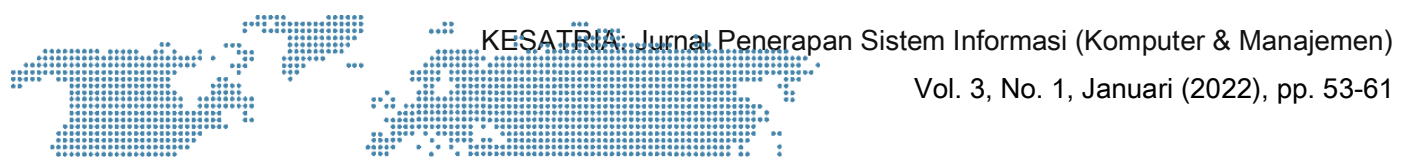

\title{
Penerapan Data Mining Dalam Menentukan Kelayakan Penerima Bantuan Sosial Pemko Dengan Algoritma C4.5 (Kasus Kantor Kelurahan Martoba)
}

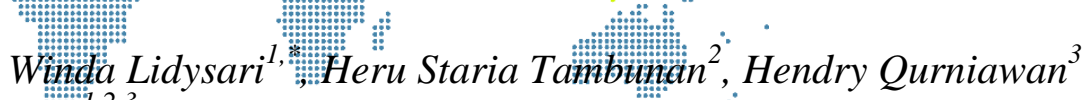 \\ "', "2,3 STIKOM Tunas Bangsa, Pemätangisiantar, Indonesia \\ Email: ${ }^{1 *}$ windalidyasari25@gmail.com, ${ }^{2}$ herusatria@amiktunasbangsa.ac.id, \\ 3,"*hendryq@amiktunasbangsa.ac.id
}

\begin{abstract}
Social assistance, commonly known as Bansos, is a government program charged by the Regional Revenue and Expenditure Budget. According to the general provisions of article 15 of the Ministerial Regulation Number 32 of 2011 concerning the Provision of Subsidies and Social Assistance in the Regional Revenue and Expenditure Budget, the definition of social assistance applies to the provision of individuals, families, community groups that are unsustainable and selective in nature to prevent possible social risks. The Pematangsiantar City Government provides various kinds of assistance programs, one of which is the PEMKO Social Assistance which is distributed by the Martoba Village Office. In the selection process to determine the recipients of PEMKO Social Assistance at the Martoba Village Office, they still have not fully used information technology to support employee performance. So there are obstacles and it takes a long time. Therefore, we need a system that can help employees more easily determine beneficiaries. Application of Data Mining is a series of processes to find added value semi-manually in the form of unknown knowledge from a data set. In this study, it has parameters, namely, the number of dependents, work, income and home status. By applying the Data Mining Algorithm C4.5, it is hoped that it will make it easier and faster for employees to determine the recipients of PEMKO Social Assistance at the Martoba Village Office.
\end{abstract}

Keywords: Data Mining, C4.5 Algorithm, Assistance Program

\begin{abstract}
Abstrak
Bantuan sosial yang biasa disebut Bansos merupakan program pemerintah yang dibebankan oleh Anggaran Pendapatan dan Belanja Daerah. Menurut ketentuan umum pasal 15 Peraturan Menteri Nomor 32 Tahun 2011 tentang Pemberian Subsidi dan Bantuan Sosial dalam Anggaran Pendapatan dan Belanja Daerah, pengertian bantuan sosial berlaku untuk pemberian perorangan, keluarga, kelompok masyarakat yang bersifat tidak berkelanjutan.dan bersifat selektif untuk mencegah kemungkinan risiko sosial. Pemerintah Kota Pematangsiantar menyediakan berbagai macam program bantuan salah satunya Bantuan Sosial PEMKO yang penyalurannya dilakukan oleh Kantor Kelurahan Martoba. Dalam proses seleksi menentukan penerima Bantuan Sosial PEMKO pada Kantor Kelurahan Martoba masih belum sepenuhnya menggunakan teknologi informasi untuk mendukung kinerja pegawai. Sehingga adanya kendala dan membutuhkan waktu lama. Oleh karena itu, diperlukannya suatu sistem yang dapat membantu pegawai lebih mudah dalam menentukan penerima bantuan. Penerapan Data Mining adalah serangkaian proses untuk menemukan nilai tambah secara semi-manual berupa pengetahuan yang tidak diketahui dari suatu kumpulan data. Dalam penelitian ini memiliki parameter yaitu, jumlah tanggungan, pekerjaan, penghasilan dan status rumah. Dengan menerapkan Data Mining Algoritma C4.5 ini diharapkan dapat mempermudah dan mempercepat pegawai dalam menentukan penerima Bantuan Sosial PEMKO pada Kantor Kelurahan Martoba.
\end{abstract}

Kata Kunci: Data Mining, Algoritma C4.5, Program Bantuan 

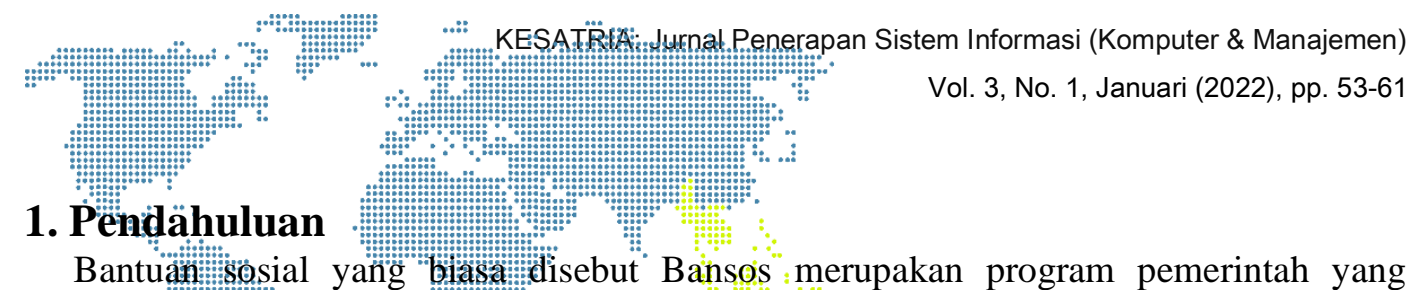

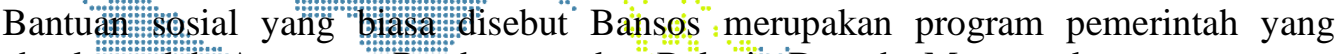
dibebankan owete:Anggaran Pendapatan dan Belanjä: Daerah. Menurut ketentuan umum Pasal 15 Peraturan Pemerintah : tentang Pembertuar Hibảh dan Bantuan Sosial dalam Anggaran Penclapatan dan Belanja Daerah Menteritom Oalam Negeri Nomor 32 Tahun 2011, pengertian Bạntuan Sosial mengacu pada ketentuan periseorangan, keluarga dan kelompok masyarakat yang sifat nya tidak berkelanjutan dan selektif untuk mencegah potensi risiko sosial[1]. Seperti yang kita ketahui, sebagian besar masyarakat di Kota Pematangsiantar adalah masyarakat kurang mampu, sehingga membutuhkan bantuan sosial untuk membantu kehidupan mereka. Kantor Kelurahan Martoba secara rutin melaksanakan program bantuan pemerintah, termasuk bantuan sosial pemko. Untuk menentukan penerima bantuan sosial pemko di Kantor Kelurahan Martoba juga ada prosedurnya yaitu dengan melakukan proses seleksi untuk setiap warga.

Proses seleksi penerima bantuan sosial pemko di Kantor Kelurahan Martoba memiliki kendala dalam mengidentifikasi penerima bantuan sosial pemko yaitu jangka waktu dari seleksi administrasi dan verifikasi sampai ke tempat tinggal penerima. Dari awal proses, berkas-berkas warga akan diperiksa dan mereka yang berhak menerima bantuan akan diseleksi sesuai kriteria yang ditentukan di bagian sosial. Dengan demikian, proses musyawarah dalam mengidentifikasi calon penerima bantuan bosial pemko tidak sistematis dan terkadang tidak tepat. Banyak cabang ilmu komputer dapat memecahkan masalah ini. Berdasarkan penjelasan di atas, peneliti menggunakan Data Mining dengan metode Algoritma C4.5 untuk menyelesaikan masalah tersebut.

Algoritma C4.5 merupakan algoritma yang digunakan untuk melakukan klasifikasi data dengan maenggunakan teknik pohon keputusan[2], [3]. Algoritma C4.5 merupakan perpanjangan dari Algoritma ID3 dan menggunakan prinsip pohon keputusan[4]. Keuntungan utama dari Algoritma C4.5 adalah dapat menghasilkan model dalam bentuk pohon atau aturan yang mudah diinterpretasikan, memiliki tingkat akurasi yang dapat diterima dan dapat menangani atribut diskrit dan numerik[5]. Pada Algoritma C4.5 model yang dihasilkan dari proses pembelajaran dari data latih berupa Decision Tree[6].

\section{Metodologi Penelitian}

\subsection{Metode Penelitian}

Penelitian ini dilakukan untuk mengimplementasikan Data Mining dalam menentukan pola penyusunan berkas yang terdapat di Kantor Kelurahan Martoba Pematangsiantar[7]. Adapun metode yang digunakan dalam penelitian yang dilakukan oleh peneliti adalah metode Algoritma C4.5. pada metodologi penelitian ini akan diuraikan proses cara ilmiah untuk mendapatkan data yang akan digunakan dalam penelitian pemecahan suatu masalah[8], [9].

\subsection{Rancangan Penelitian}

Rancangan penelitian merupakan kerangka penelitian atau alur penelitian yang dilakukan oleh peneliti. Pada rancangan penelitian ini akan dibuat perincian atau tahap keseluruhan proses penelitian, mulai dari pengumpulan data hingga memproleh kesimpulan dan hasil akhir yang didapat oleh peneliti, sehingga menghasilkan sebuah keputusan yang dapat menjadi masukan untuk pegawai Kantor Kelurahan Martoba[10]. Adapun alur rancangan dari penelitian ini dapat dilihat pada Gambar 1 dibawah ini[11]: 


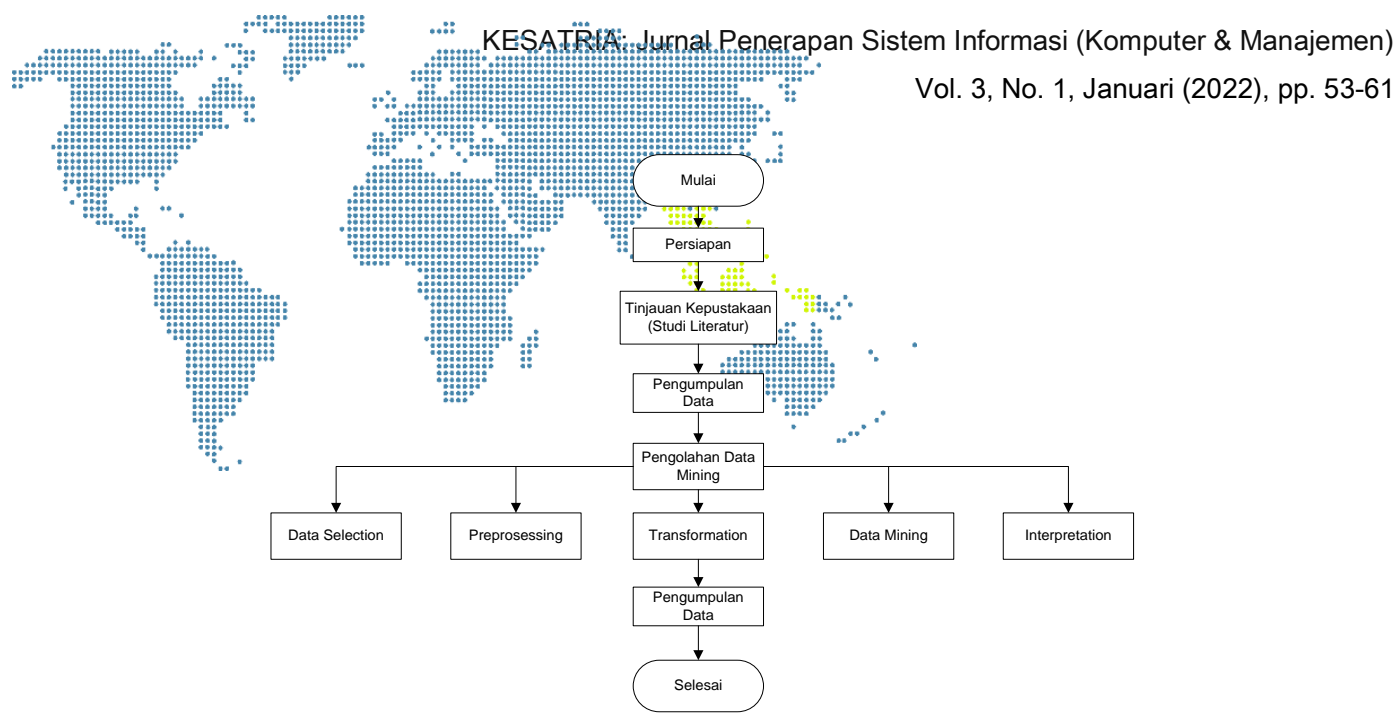

Gambar 1. Rancangan Penelitian

Gambar 1 menjelaskan rancangan penelitian yang dilakukan untuk mencari daerah dengan hasil produksi sawit yang belum optimal dengan Algoritma C4.5 yang terdiri dari[12] :

a) Kerangka penelitian yang dituangkan dalam diagram alir ini. Menggambar proses penelitian yang akan ditempuh sekaligus menggambarkan penelitian secara keseluruhan. Tahapan yang akan ditempuh yaitu:

b) Persiapan. Tahap ini merupakan tahapan subjek (populasi) perpustakaan UIN Raden Fatah Palembang. Objek yang diambil yaitu buku. Batasan dan menyusun rencana penelitian.

c) Tinjauan kepustakaan. Dalam tinjauan kepustakaan dilakukan telaah slims perpustakaan dan studi literatur mengenai peminjaman buku dan yang berhubungan.

d) Pengumpulan data. Pengumpulan data dilakukan dengan cara wawancara kepada staf perpustakaan, observasi dan dokumen.

e) Pengolahan data mining. Data yang dikumpulkan diolah sesuai dengan tahapan Knowledge Discovery in Database (KDD).

f) Data Selection, Proses seleksi atau pemilihan data yang relevan terhadap analisis untuk diterima dari koleksi data yang ada.

g) Preproccesing, Sebelum proses data mining dapat dilaksanakan, perlu dilakukan proses cleaning pada data yang menjadi fokus KDD. Proses cleaning mencakup antara lain membuang duplikasi data, memeriksa data yang inkonsisten, dan memperbaiki kesalahan pada data.

h) Data Transformation, Proses transformasi data yang sudah dipilih ke dalam bentuk mining procedure melalui cara dan agresi data.

i) Data Mining, Proses yang paling penting dimana akan dilakukan berbagai teknik yang diaplikasikan untuk mengekstrak berbagai pola-pola potensial untuk mendapatkan data yang berguna.

j) Interpretation, Sebuah proses dimana pola-pola menarik yang sebelumnya sudah ditemukan dengan identifikasi berdasarkan measure yang telah diberikan.

k) Pengumpulan Data, pembahasan pada tahapan ini menjelaskan hasil dari proses data mining yang dilakukan dengan menggunakan algoritma C4.5.

1) Kesimpulan dan saran. Membuat kesimpulan dari hasil penelitian dan memberikan.

\subsection{Analisis Data}

Proses analisis data dilakukan setelah proses pengumpulan data selesai. Dalam penelitian ini data yang sudah didapatkan oleh peneliti digunakan untuk data penelitian, 


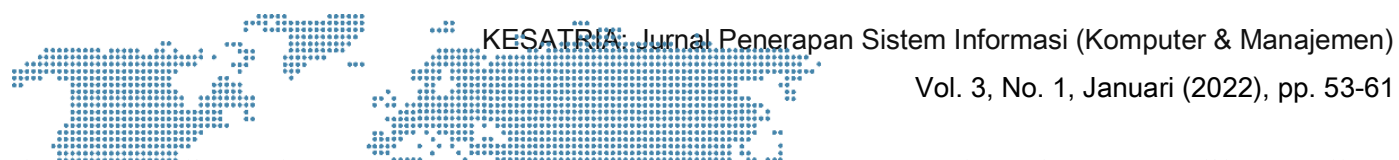

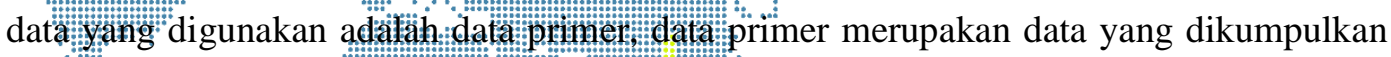
langsung "oleh penelititu buasunyal data primer dikumpulkan melalui observasi dan wawancẩ. penelitian

a) Miciosoft Excel

Microsoft Excel merupakan perangkat linalek:yang berfungsi untuk mengolah data, dimạna pada aplikasi ini berupa spreadsheèt yang dibuat serta didistribusikan oleh Microsoft Corporation untuk dapat digunakan pada sistem operasi Windows dan juga Mac OS. Penggunaan Microsoft Excel pada penelitian ini untuk mengolah data sementara agar mendapatkan hasil yang cepat.

b) RapidMiner

RapidMiner merupakan perangkat lunak yang digunakan pada pengolahan Data Mining, penggunaan RapidMiner digunakan untuk memperoleh hasil pengujian yang valid dengan hasil perhitungan sebelumnya yang dilakukan di Micosoft Excel.

\subsection{Pemodelan Metode}

Metode yang digunakan pada penelitian ini adalah Algoritma C4.5. dalam pemodelan Algoritma C4.5 dilakukan sampel dataset, kemudian menghitung Entrophy (S) dari keseluruhan atribut, setelah Entrophy (S) ditemukan kemudian perhitungan Gain tertinggi dari seluruh atribut, atribut yang memiliki Gain tertinggi yang akan digunakan sebagai akar/node. Selanjutnya buat cabang untuk setiap nilai, bagi kasus dalam cabang, ulangi perhitungan Gain sampai semua data masuk ke dalam kelas yang sama. Atribut yang telah dipilih tidak lagi dibutuhkan dalam perhitungan, proses pembentukkan pohon keputusan terhenti jika sudah tidak ada lagi atribut yang dipartisi dan semua tuple dalam node $\mathrm{N}$ telah memiliki kelas yang sama. Dalam kasus dataset pada penlitian ini terdiri dari 2 kelas. keterangan nya yaitu Layak (+) dan Tidak Layak (-). Berikut diagram alur kerja pemodelan Algoritma C4.5.

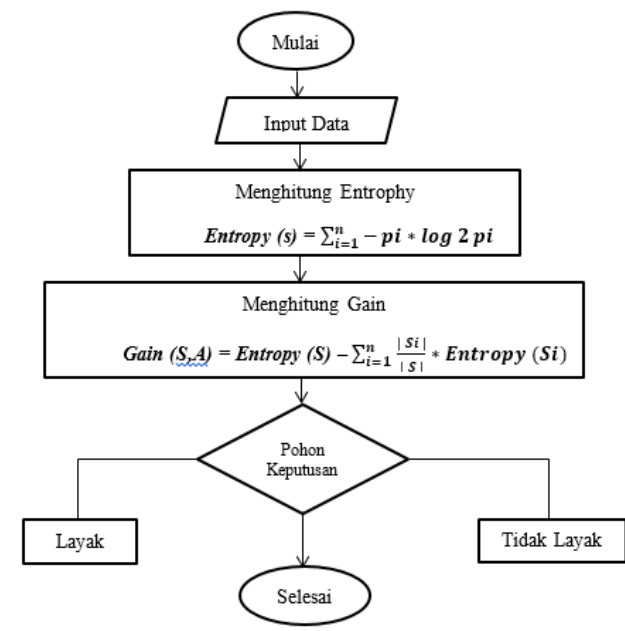

Gambar 2. Pemodelan Algoritma C4.5
$\mathrm{S} \quad=$ Himpunan kasus
A $=$ Atribut
$\mathrm{N}=$ Jumlah partisi atribut $\mathrm{A}$
$|\mathrm{Si}|=$ Proporsi $\mathrm{S}$ terhadap $\mathrm{Si}$
$|\mathrm{S}|=$ Jumlah kasus dalam $\mathrm{S}$
$\mathrm{Pi}=$ Proporsi Si terhadap $\mathrm{S}$
$\mathrm{N}=$ Jumlah partisi $\mathrm{S}$ 


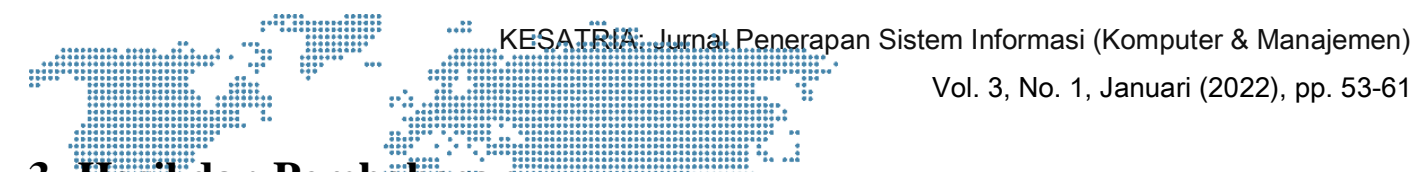

\section{Hasil dan Pembähasan}

\subsection{Hasil}

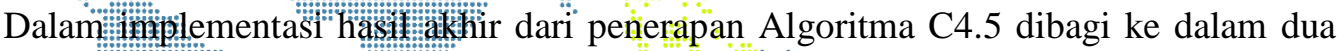
tahap yauiti proses perhifingan semi manual menggunakan Microsoft Excel dan

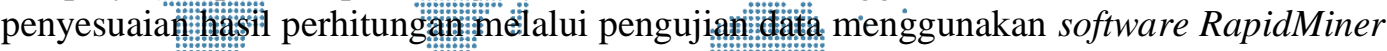
5.3.

\subsubsection{Analsis Sistem}

Analisis sistem bertujuan untuk menemukan pola baru penentuan penerima bantuan sosial pemko dengan menggunakan Data Mining klasifikasi Algoritma C4.5. Proses pemilihan penerima bantuan sosial pemko memiliki kendala waktu sehingga proses penyelesaiannya tidak berlangsung secara sistematis dan terkadang tidak tepat sasaran. Dalam hal ini, sumber data diperoleh dari Kantor Kelurahan Martoba. Berdasarkan hasil rekapitulasi, digunakan 200 sampel data untuk klasifikasi Algoritma C4.5 dalam penentuan penerima bantuan sosial pemko. Kriteria yang digunakan ada 4 yaitu jumlah tanggungan, pekerjaan, pendapatan dan status rumah. Tabel 1 menunjukkan potongan hasil pengumpulan field-field dan data penerima bantuan sosial pemko yang digunakan sebagai data pelatihan dalam proses data mining.

Tabel 1. Data Penerima Bantuan Sosial Pemko

\begin{tabular}{|c|c|c|c|c|c|c|}
\hline No & Nama & Jumlah Tanggungan & Pekerjaan & Penghasilan & Status Rumah & Ket \\
\hline 1 & Erismawati & 1 & Wiraswasta & Rp. 1.000 .000 & Rumah Sendiri & Tidak Layak \\
\hline 2 & Irzahany & 2 & Wiraswasta & Rp. 2.000 .000 & Kontrakan & Layak \\
\hline 3 & M. Zailaini Ritonga & 2 & Wiraswasta & Rp. 4.000 .000 & Kontrakan & Tidak Layak \\
\hline 4 & Yusron Ritonga & 3 & Wiraswasta & Rp. 2.500.000 & Kontrakan & Layak \\
\hline 5 & Harry Swanda & 1 & Wiraswasta & Rp. 1.000 .000 & Rumah Sendiri & Tidak Layak \\
\hline . & . & . & . & . & . &. \\
\hline . & . & . & . & . & . & \\
\hline . & . & . & . & . & . & . \\
\hline 195 & Norbet Sinaga & 5 & Wiraswasta & Rp. 2.000 .000 & Rumah Sendiri & Layak \\
\hline 196 & Nazarudin Siregar & 2 & Wiraswasta & Rp. 1.000 .000 & Rumah Sendiri & Tidak Layak \\
\hline 197 & Welcom Syahputra & 2 & Wiraswasta & Rp. 1.000 .000 & Rumah Sendiri & Tidak Layak \\
\hline 198 & Samsul Bahri & 2 & Wiraswasta & Rp. 1.000 .000 & Rumah Sendiri & Tidak Layak \\
\hline 199 & Hasnil Ritonga & 2 & Wiraswasta & Rp. 2.000 .000 & Kontrakan & Layak \\
\hline 200 & Irwan Efendi & 6 & Wiraswasta & Rp. 2.000.000 & Kontrakan & Layak \\
\hline
\end{tabular}

\subsubsection{Proses Perhtiungan Algoritma $\mathbf{C} 4.5$}

Perhitungan Algoritma C4.5 untuk memperoleh model aturan pohon keputusan terlebih dahulu mencari jumlah kasus keseluruhan, jumlah kasus keputusan Layak dan Tidak Layak. Menghitung Entropy dari semua kasus dan kasus yang dibagi berdasarkan kelas atribut dengan persamaan (1).

Selanjutnya dilakukan penghitungan Gain untuk masing-masing atribut dengan persamaan (2). Berikut ini adalah perhitungan nilai entropy dan gain.

\section{Menghitung entropy total :}

Entropy $_{[\text {Total }]}=\left(-\frac{102}{200} x \log _{2}\left(\frac{102}{200}\right)\right)+\left(-\frac{98}{200} x \log _{2}\left(\frac{98}{200}\right)\right)=0,9997114$

\section{Menghitung entropy dan gain Jumlah Tanggungan :}

\section{Entropy [Jumlah Tanggungan-Tidak Ada]}

Entropy [Jumlah Tanggungan-Sedikit]

Entropy [Jumlah Tanggungan-Cukup Banyak]

Entropy [Jumlah Tanggungan-Banyak]

$$
\begin{aligned}
& =0 \\
& =\left(-\frac{39}{115} x \log _{2}\left(\frac{39}{115}\right)\right)+\left(-\frac{76}{115} x \log _{2}\left(\frac{76}{115}\right)\right) \\
& =0,9239842 \\
& =0 \\
& =\left(-\frac{3}{16} x \log _{2}\left(\frac{3}{16}\right)\right)+\left(-\frac{13}{16} x \log _{2}\left(\frac{13}{16}\right)\right) \\
& =0,6962123
\end{aligned}
$$




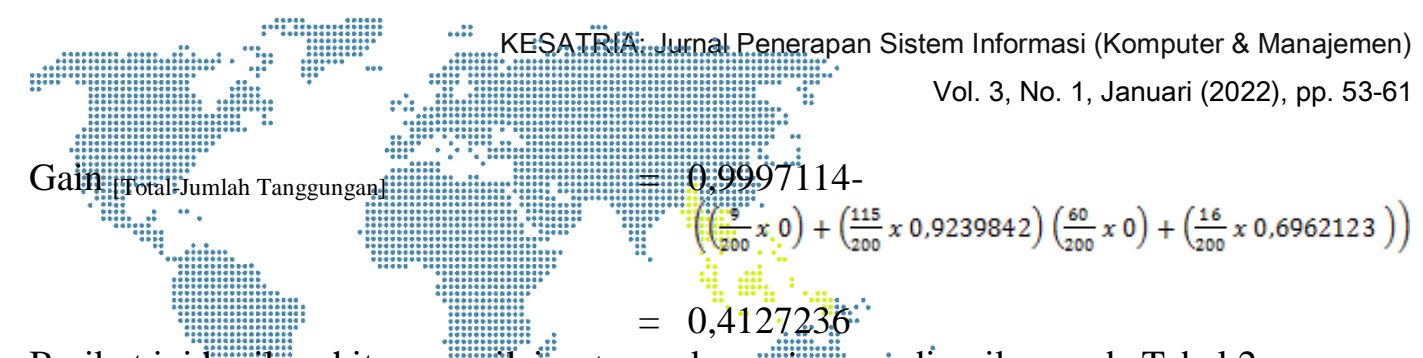

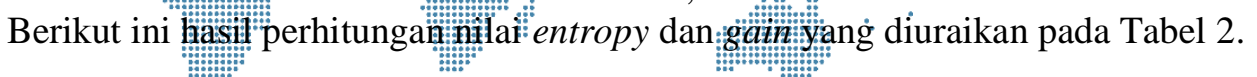

Tabel 2. Perhitungan Nöde 1

\begin{tabular}{|c|c|c|c|c|c|c|}
\hline Node 1 & Ket & Jumlah Kasus & Layak & Tidak Layak & Entropi & Gain \\
\hline Total & & 200 & 102 & 98 & 0,9997114 & \\
\hline $\begin{array}{c}\text { Jumlah } \\
\text { Tanggungan }\end{array}$ & & & & & & 0,4127236 \\
\hline & Tidak Ada & 9 & 0 & 9 & 0 & \\
\hline & Sedikit & 115 & 39 & 76 & 0,9239842 & \\
\hline & Cukup Banyak & 60 & 60 & 0 & 0 & \\
\hline & Banyak & 16 & 3 & 13 & 0,6962123 & \\
\hline Pekerjaan & & & & & & 0,0022197 \\
\hline & Wiraswasta & 146 & 72 & 74 & 0,9998646 & \\
\hline & Wirausaha & 54 & 30 & 24 & 0,9910761 & \\
\hline Penghasilan & & & & & & $\mathbf{0 , 8 4 7 4 3 5 9}$ \\
\hline & Rendah & 49 & 3 & 46 & $\mathbf{0 , 3 3 2 2 8 6 6}$ & \\
\hline & Menengah & 101 & 99 & 2 & 0,1403273 & \\
\hline & Tinggi & 50 & 0 & 50 & 0 & \\
\hline Status Rumah & & & & & & 0,0531889 \\
\hline & Rumah Sendiri & 99 & 37 & 62 & 0,9534986 & \\
\hline & Kontrakan & 101 & 65 & 36 & 0,9396847 & \\
\hline
\end{tabular}

Dari hasil perhitungan pada tabel 2 diperoleh atribut yang menjadi node (akar) adalah Penghasilan memiliki gain tertinggi 0,8474359, dimana terdiri dari 3 sub atribut yaitu Rendah, Menengah dan Tinggi. Berdasarkan nilai entrophy dari ketiga sub atribut diatas, sub atribut Rendah yang memperoleh keputusan. Maka perlu dilakukan perhitungan lebih lanjut menentukan node akar selanjutnya, dapat digambarkan pohon keputusan dari tabel diatas sebagai berikut:

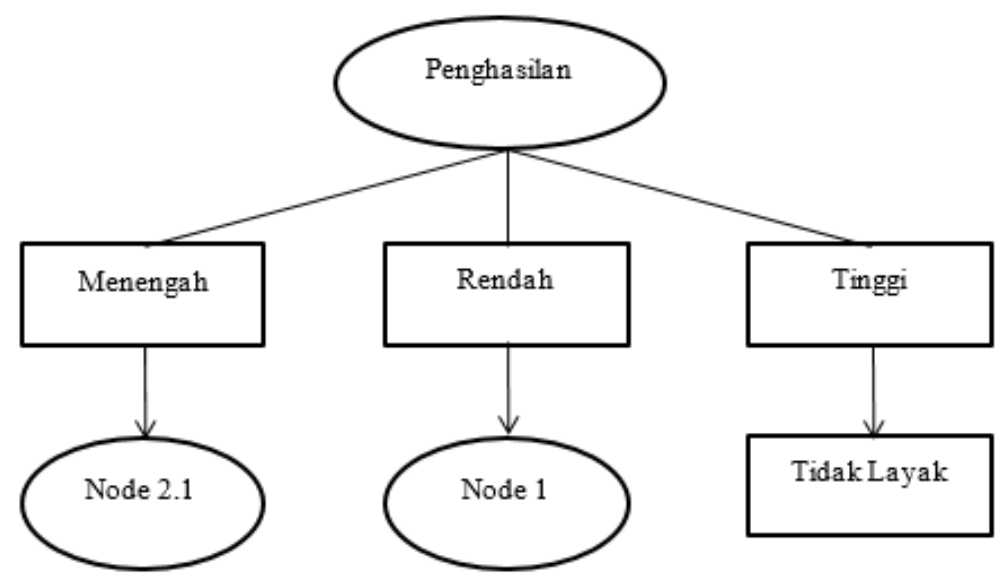

Gambar 2. Pohon Keputusan 1

Hingga atribut yang menjadi node cabang dari Penghasilan-Rendah dan Status RumahKontrakan adalah Jumlah Tanggungan, dimana atribut dari Jumlah Tanggungan yang terdiri dari Tidak Ada, Sedikit, Cukup Banyak dan Banyak. Dimana Jumlah TanggunganTidak Ada sudah memperoleh keputusan tidak layak dan Jumlah Tanggungan-Sedikit sudah memperoleh keputusan layak. Maka proses perhitungan telah selesai dilakukan. 


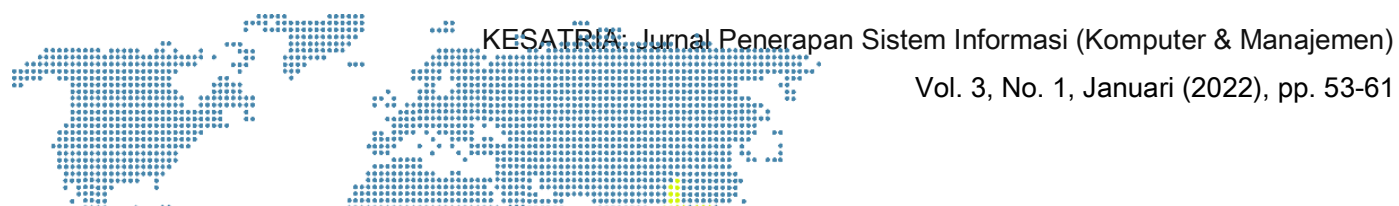

3.1.3. Pröses Percobăan a tgoitina C4.5 Menggunakan Rapidminer

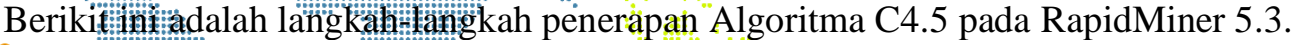

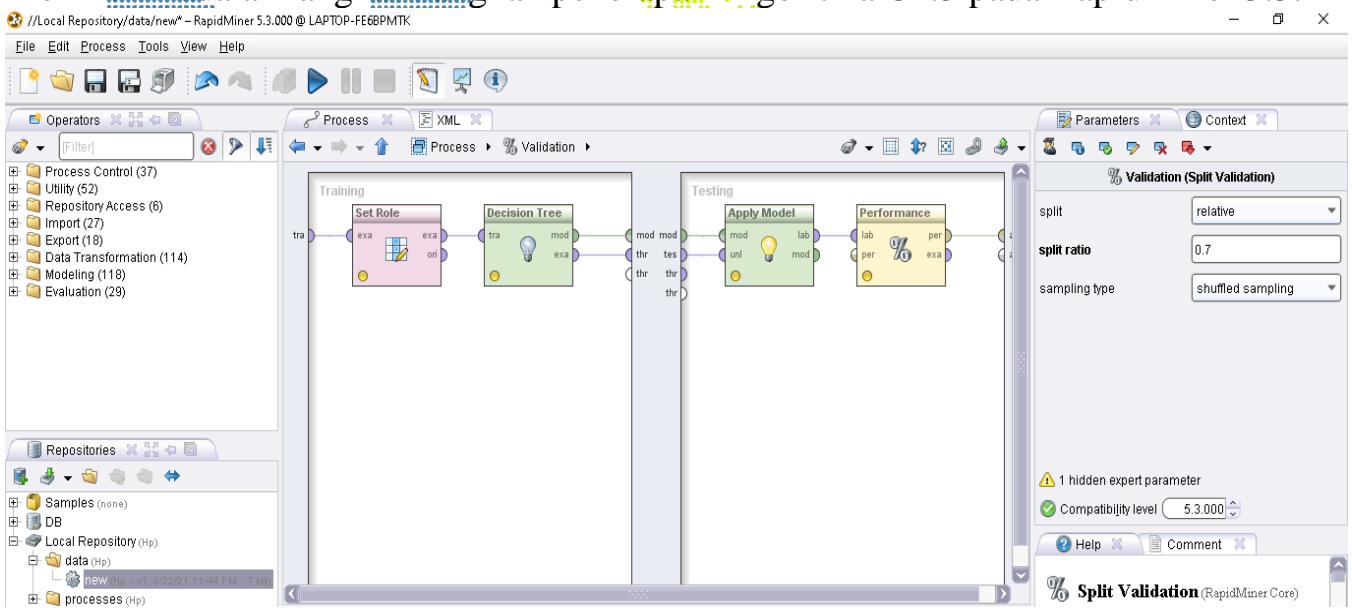

Gambar 3. Tampilan Menghubungkan Port Decision Tree, Apply Model Dan Performance

Selanjutnya hubungkan port-port dari operator Decision Tree, operator Apply Model dan operator Performance seperti gambar diatas, kemudian klik icon Run pada toolbar untuk menampilkan hasil

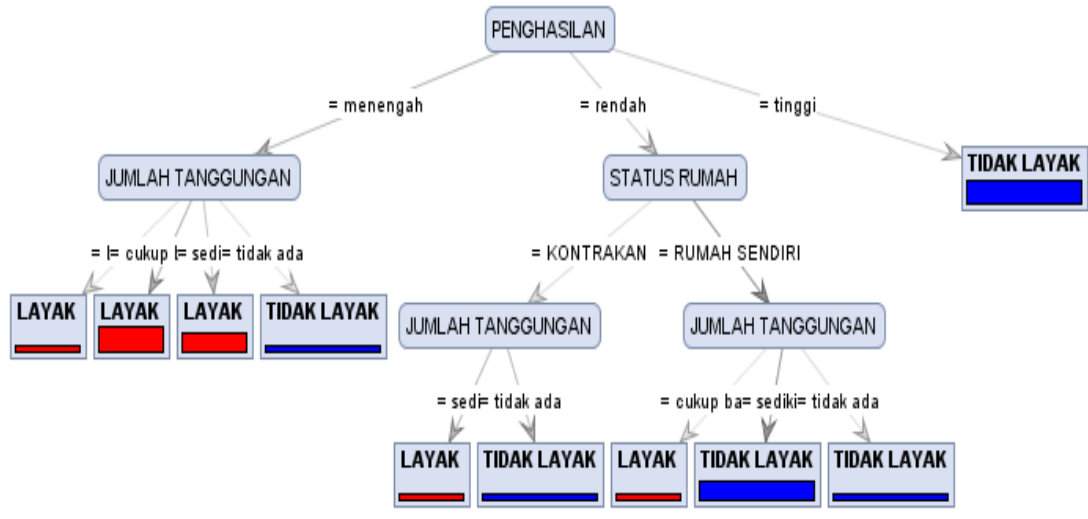

Gambar 4. Tampilan Hasil Decesion Tree

Setelah dilakukan perhitungan dan pengujian data pada masing-masing atribut dengan algoritma C4.5, maka akan didapatkan pola pohon keputusan akhir.

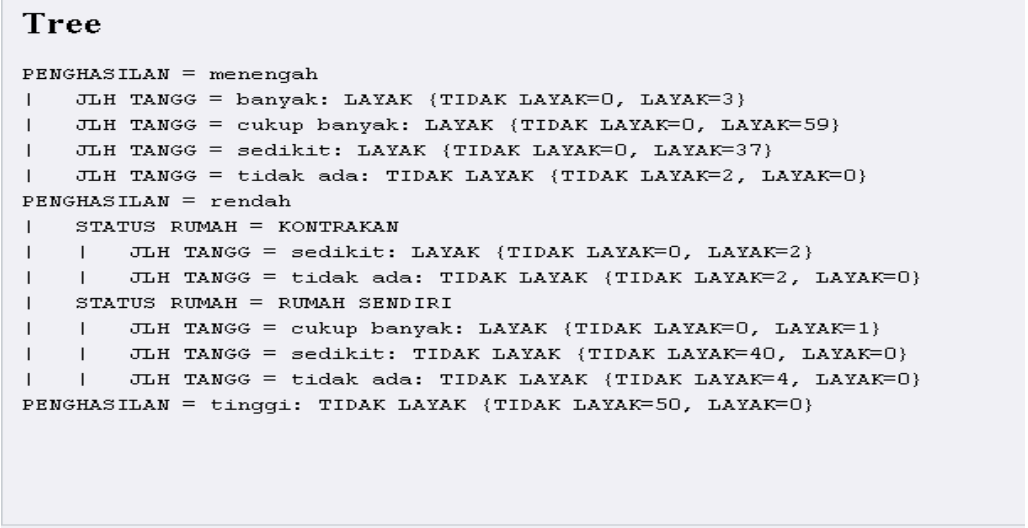

Gambar 5. Rule Decision Tree Pada Rapidminer 


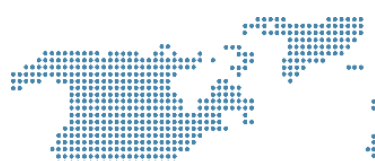

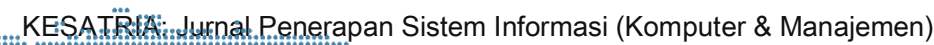

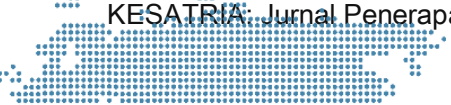

Vol. 3, No. 1, Januari (2022), pp. 53-61

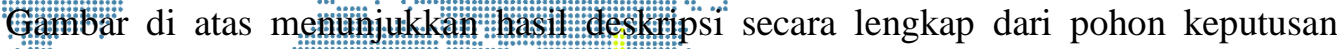
(Decision" Tree) yang telaht terbentuk dengan menggunakan Algoritma C4.5. Dari hasil

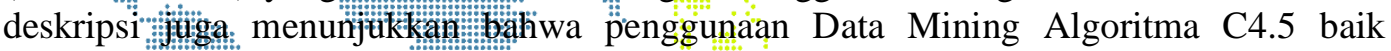
digunakantualatim: proses mengegali data (Data Mining process) untuk menarik beberapa kesimpulan yang: divisualisâsikan dengan pohon keputusan (Decision Tree).

\subsection{Pembahasan}

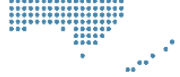

Berikut ini rules yang dihasilkan dari pohon keputusan tersebut :

Tabel 3. Rule Yang Dihasilkan

\begin{tabular}{|c|lr|c|}
\hline No & \multicolumn{1}{|c|}{ Rules } & Keputusan \\
\hline 1 & $\begin{array}{l}\text { Jika Penghasilan = Menengah (Rp. 2.000.000 } \\
\text { Tanggungan = Banyak }\end{array}$ & Rp. 2.500.000) dan Jumlah & Layak \\
\hline 2 & $\begin{array}{l}\text { Jika Penghasilan = Menengah (Rp. 2.000.000 } \\
\text { Tanggungan = Cukup Banyak }\end{array}$ & Rp. 2.500.000) dan Jumlah & Layak \\
\hline 3 & $\begin{array}{l}\text { Jika Penghasilan = Menengah (Rp. 2.000.000 } \\
\text { Tanggungan = Sedikit }\end{array}$ & Rp. 2.500.000) dan Jumlah & Layak \\
\hline 4 & $\begin{array}{l}\text { Jika Penghasilan = Menengah (Rp. 2.000.000 - Rp. 2.500.000) dan Jumlah } \\
\text { Tanggugan = Tidak Ada }\end{array}$ & Tidak Layak \\
\hline 5 & $\begin{array}{l}\text { Jika Penghasilan = Rendah dan Status Rumah = Kontrakan dan Jumlah } \\
\text { Tanggungan = Sedikit }\end{array}$ & Layak \\
\hline 6 & $\begin{array}{l}\text { Jika Penghasilan = Rendah (Rp. 1.000.000) dan Status Rumah = Kontrakan dan } \\
\text { Jumlah Tanggungan = Tidak Ada }\end{array}$ & Tidak Layak \\
\hline 7 & $\begin{array}{l}\text { Jika Penghasilan = Rendah (Rp. 1.000.000) dan Status Rumah = Sedikit dan } \\
\text { Jumlah Tanggungan = Cukup Banyak }\end{array}$ & Layak \\
\hline 8 & $\begin{array}{l}\text { Jika Penghasilan = Rendah (Rp. 1.000.000) dan Status Rumah = Rumah Sendiri } \\
\text { dan Jumlah Tanggungan = Sedikit }\end{array}$ & Tidak Layak \\
\hline 9 & $\begin{array}{l}\text { Jika Penghasilan = Rendah (Rp. 1.000.000) dan Status Rumah = Rumah Sendiri } \\
\text { dan Jumlah Tanggungan = Tidak Ada }\end{array}$ & Tidak Layak \\
\hline 10 & Jika Penghasilan = Tinggi (Rp. 3.000.000 - $\quad$ Rp. 4.000.000) & Tidak Layak \\
\hline
\end{tabular}

\begin{tabular}{|c|c|c|c|}
\hline \multicolumn{3}{|c|}{ (1) Muticlass Classification Performance $\bigcirc$ Annotations } & \multirow[t]{2}{*}{ X百。 } \\
\hline \multicolumn{3}{|c|}{ (1) Table View O Plotview } & \\
\hline \multicolumn{4}{|l|}{ accuracy: 100.00\% } \\
\hline & true TIDAK LAYAK & true LAYAK & class precision \\
\hline pred. TIDAK LAYAK & 25 & 0 & $100.00 \%$ \\
\hline pred. LAYAK & 0 & 35 & $100.00 \%$ \\
\hline class recall & $100.00 \%$ & $100.00 \%$ & \\
\hline
\end{tabular}

Gambar 6. Nilai Akurasi Algoritma C4.5

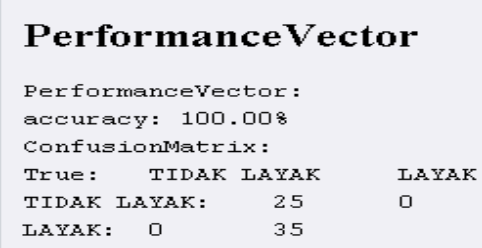

Gambar 7. Nilai Performance Vector Algoritma C4.5

Berdasarkan pengolahan data menggunakan software RapidMiner didapat nilai akurasi sistem sebesar $100 \%$, artinya. Dimana model yang telah dibentuk diuji tingkat akurasinya dengan memasukan atau uji yang berasal dari data training dengan menggunakan split validation pada aplikasi RapidMiner 5.3 untuk menguji tingkat akurasi. 


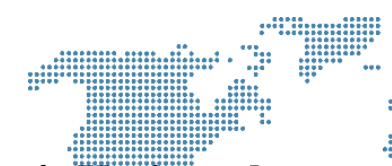

\section{Kesinpulan}

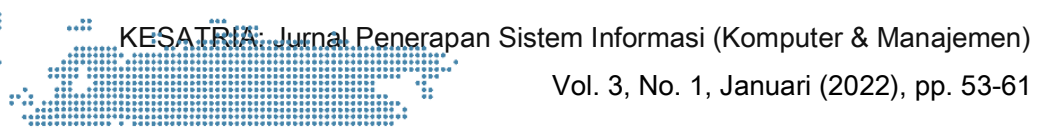

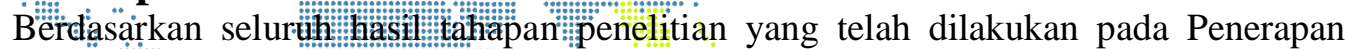

Data Minum Algoritma: (e) berikut.

a) Data Mining dengan Alyoritma C4.5 dapat diterapkan untuk Penentuan Kelayakan Penerimä. Bantuan Sosial Pemko pada Kantor "Kelurahan Martoba. Hasil yang diperoleh dari pengujian metode Algoritma C4.5 kedalam RapidMiner memiliki nilai validasi yang sama.

b) Permasalahan menentukan kelayakan penerima bantuan sosial Pemko dapat diselesaikan menggunakan teknik Data Mining, yaitu dengan Algoritma C4.5. Menghasilkan tingkat akurasi yang dihasilkan oleh metode tersebut adalah $100 \%$.

c) Dari perhitungan dengan Algoritma C4.5 maka didapatkan faktor yang paling dominan adalah Penghasilan dengan nilai gain sebesar 0,8474359.

\section{Daftar Pustaka}

[1] N. Fajira, "Analisis Kepuasan Pelanggan Terhadap Kualitas Pelayanan Pada Kentucky Fried Chicken Cabang Palembang Square Mall," Polsri, pp. 14-20, 2014.

[2] A. D. I. Suradi, "Penerapan data mining untuk menentukan rekomendasi beasiswa dengan metode algoritma $\mathrm{c} 4.5, " 2018$.

[3] T. R. I. B. Tusarwenda, "Penerapan data mining dengan algoritma $\mathrm{c} 4.5$ dalam prediksi penjualan botol pada CV. seribukilo," 2018.

[4] Hendrianto, "Manajemen Strategi Pengelolaan Pasar Dalam Meningkatkan Pendapatan Pedagang Perspektif Ekonomi Islam (Studi di Pasar Segamas Purbalingga),” pp. 1-94, 2018.

[5] L. N. Rani, "Klasifikasi Nasabah Menggunakan Algoritma," J. KomTekInfo Fak. Ilmu Komput., vol. 2, no. 2, pp. 33-38, 2015.

[6] D. K. Widiyati, M. Wati, and H. S. Pakpahan, "Penerapan Algoritma ID3 Decision Tree Pada Penentuan Penerima Program Bantuan Pemerintah Daerah di Kabupaten Kutai Kartanegara," J. Rekayasa Teknol. Inf., vol. 2, no. 2, p. 125, 2018, doi: 10.30872/jurti.v2i2.1864.

[7] P. Alkhairi, I. S. Damanik, and A. P. Windarto, "Penerapan Jaringan Saraf Tiruan untuk Mengukur Korelasi Beban Kerja Dosen Terhadap Peningkatan Jumlah Publikasi,” Pros. Semin. Nas. Ris. Inf. Sci., vol. 1, no. September, p. 581, 2019, doi: 10.30645/senaris.v1i0.65.

[8] L. Swastina, "Penerapan Algoritma C4.5 untuk Penentuan Jurusan Mahasiswa," J. Gema Aktual., vol. 2, no. 1, pp. 93-98, 2013.

[9] A. H. Nasrullah, "Penerapan Metode C4.5 untuk Klasifikasi Mahasiswa Berpotensi Drop Out," Ilk. J. Ilm., vol. 10, no. 2, p. 244, 2018, doi: 10.33096/ilkom.v10i2.300.244-250.

[10] Y. S. Luvia, A. P. Windarto, S. Solikhun, and D. Hartama, "Penerapan Algoritma C4.5 Untuk Klasifikasi Predikat Keberhasilan Mahasiswa Di Amik Tunas Bangsa," Jurasik (Jurnal Ris. Sist. Inf. dan Tek. Inform., vol. 1, no. 1, p. 75, 2017, doi: 10.30645/jurasik.v1i1.12.

[11] S. Haryati, A. Sudarsono, and E. Suryana, "Implementasi Data Mining Untuk Memprediksi Masa Studi Mahasiswa Menggunakan Algoritma C4.5 (Studi Kasus: Universitas Dehasen Bengkulu)," J. Media Infotama, vol. 11, no. 2, pp. 130-138, 2015.

[12] A. P. W. Putrama Alkhairi, "Penerapan K-Means Cluster Pada Daerah Potensi Pertanian Karet Produktif di Sumatera Utara." 2019.

[13] W. A. Triyanto, "Algoritma K-Medoids Untuk Penentuan Strategi Pemasaran Produk," J. SIMETRIS, vol. 6, no. 1, pp. 183-188, 2015. 